\title{
SEISMIC SOURCES AND MAIN SEISMIC FAULTS IN THE AEGEAN AND SURROUNDING AREA
}

\author{
G.F. Karakaisis, C.B. Papazachos, and E.M. Scordilis \\ Department of Geophysics, School of Geology, Faculty of Science, Aristotle University, GR54124, Thessa- \\ loniki,GREECE,karakais@geo.auth.gr,kpapaza@geo.auth.gr,manolis@geo.auth.gr
}

\begin{abstract}
A seismic source is defined, in the present work, as the part of the seismogenic layer of the earth's crust with a circular horizontal dimension $(E, R)$, where $E$ is the epicenter of the largest earthquake (mainshock) ever occurred in this seismic source and radius equal to the half fault length of this largest earthquake $(R=L / 2)$. In addition to foreshocks and aftershocks other smaller mainshocks occur in other smaller faults of this source or in parts of the main fault.

All available historical and instrumental data concerning strong $\left(M^{3} 6.0\right)$ shallow $(h \leq 60 \mathrm{~km})$ and intermediate depth $(60 \mathrm{~km}<h \leq 100 \mathrm{~km})$ shocks which occurred in the Aegean area between 464 B.C. and 2008 are used in the present work in an attempt to identify the seismic sources in this area, as well as to determine the basic parameters of the largest fault in each source. A particular procedure is followed to identify 155 seismic sources in this area and determine the basic parameters of the largest fault in each source. Declustering has been also performed to define mainshocks in the Aegean area and the completeness of this mainshock catalogue has been determined. Results are summarized in table (1).
\end{abstract}

\section{Introduction}

It is well known that the generation of strong earthquakes is a result of seismic slip on large seismic faults and that the seismic energy (and seismic moment) released by an earthquake is proportional to the dimensions of the ruptured fault and to the slip on this fault (Aki, 1966). It is also known that fault rupture is due to the relative movement of huge crustal blocks (Reid, 1911).

The largest earthquake in a region (characteristic earthquake) is due to the break of the largest (main) fault of this region and this break is repeated at relatively long time intervals (Schwartz and Coppersmith, 1984). Smaller earthquakes occur more frequently by rupture of parts (segments) of the main fault or of smaller faults in the nearby region (vicinity of the main fault). The region which includes the main (largest) fault as well as the nearby smaller faults and has a (linear) dimension equal to the length of the main fault is called focal region in the present work.

Much work has been done to locate and study seismic faults in the Aegean area by using seismological and geological data. Thus, Papazachos and his colleagues (2001) combined seismological and geological data to determine properties of 159 seismic faults where 567 strong shallow earthquakes occurred in the Aegean area since antiquity.

The purpose of the present paper is to use seismological data (location of earthquakes, fault plane so- 
lutions) to define focal regions and the corresponding main faults where all known strong ( $\left.\mathrm{M}^{3} 6.0\right)$ earthquakes with depth $\mathrm{h}<100 \mathrm{~km}$ occurred since $464 \mathrm{BC}$ in the Aegean area $\left(34^{\circ} \mathrm{N}-43^{\circ} \mathrm{N}, 18^{\circ} \mathrm{E}-30^{\circ} \mathrm{E}\right)$.

\section{The Data}

The data used in the present study are instrumental, which concern earthquakes that occurred in the Aegean area since 1911 when the first seismograph was installed in Athens (a two-horizontal component Mainka type mechanical seismograph), and historical, which concern strong earthquakes $\left(\mathrm{M}^{3} 6.0\right)$ that occurred in the same region since $464 \mathrm{BC}$. The parameters (origin time, epicenter coordinates and magnitude) for the instrumental period (1911-2008) are based mainly on seismographic records and partly on macroseismic information (Papazachos et al., 2009) while these parameters for historical earthquakes are entirely based on macroseismic information (Papazachos and Papazachou, 2003).

The data required for the present study must be accurate to a reasonable degree and homogeneous in respect to the magnitude of earthquakes. These data must also be complete, that is, the data sample used must include all earthquakes which occurred in a certain region during a certain time interval and have magnitudes larger than a certain value. Accuracy concerns location of earthquake focus and earthquake magnitude. The present study deals with shallow $(\mathrm{h} \leq 60 \mathrm{~km})$ and intermediatedepth $(60 \mathrm{~km}<\mathrm{h} \leq 100 \mathrm{~km})$ earthquakes. The error in the epicenter coordinates is about $20 \mathrm{~km}$. The error in the magnitude is 0.3 or less. All magnitudes are in the moment magnitude scale. Completeness of the instrumental data is as follows:

$\mathrm{M} \geq 5.2,1911-2008$

That is, the data samples include all earthquakes which have moment magnitude equal to or larger than 5.2 and occurred in the Aegean area between 1.1.1911 and 31.12.2008. The completeness for the historical data (464BC-1910) is examined in section (7). The earthquake catalogues used in the present study can be found at the site http://geophysics.geo. auth.gr/ss/station_index_en.html/.

\section{Determination of Focal Regions in the Aegean}

The focal region of a shallow mainshock is defined, in the present work, as the part of the seismogenic layer which cuts the earth's surface in a circle with center, E, the epicenter of the mainshock and radius equal to the half of the length of the fault ruptured during the generation of the mainshock (the focal region, actually, is a cylindrical part of the crust with height equal to the thickness of the seismogenic layer). In a first approximation the length, $\mathrm{L}$ (in $\mathrm{km}$ ), of the faults in the Aegean area is given by the relation:

$$
\log \mathrm{L}=0.51 \cdot \mathrm{M}-1.85
$$

where $\mathrm{M}$ is the moment magnitude of the earthquake (Papazachos and Papazachou, 2003). Relation (2) is used to calculate the fault length, $\mathrm{L}_{\max }$, of the largest earthquake ever occurred in the focal region and the radius of this focal region is $\mathrm{R}=\mathrm{L}_{\max } / 2$. Smaller mainshocks also occur in the focal region by rupturing of other smaller faults or parts of the main fault. Thus, to determine $\mathrm{E}$ and $\mathrm{R}$ for each focal region of the Aegean area the following procedure has been applied by using the earthquake catalogue ( $M \geq 6.0$ since 464BC, $M \geq 5.2$ since 1911) described in section (2).

First, the epicenter of the largest earthquake of the catalogue is considered as the center, E, of the largest focal region in the Aegean and its magnitude is used to calculate L by relation (2) and the radius $\mathrm{R}(=\mathrm{L} / 2)$ of this region. All earthquakes with epicenters within this region are excluded from 
the original catalogue and the same procedure is applied in the remaining part of the catalogue to determine the second largest focal region in the Aegean area. This procedure is repeated for the third, fourth, etc. largest focal region of the Aegean till all earthquakes with $M \geq 6.0$ are excluded from the catalogue. In cases when more than one earthquakes of equal magnitude are the largest in the remaining catalogue, they are sorted by decreasing origin time and the corresponding focal regions are defined in this order, i.e. the most recent largest earthquake is firstly considered, then the second most recent largest earthquake, etc. For the mainshocks of the catalogue with $\mathrm{M}<6.5$ the radius of the focal region based on relation (2) is within the error range of the epicenter location. For this reason, in such cases this radius is taken equal to $15 \mathrm{~km}$. It must be also noted that the well documented earthquakes in the Aegean area have moment magnitudes $M \leq 7.6$. For this region the maximum radius of the focal regions in the Aegean area was considered equal to $53 \mathrm{~km}$. There are, however, two earthquakes in the catalogue (365 A.D., 1303) for which larger magnitudes have been estimated, but such big earthquakes have a very large return period ( $1000 \mathrm{yrs})$ and only parts of their faults usually break. Magnitudes equal to 7.7 have been assigned for both these earthquakes for the purpose of the present paper.

After the application of the procedure described above 218 shallow circular focal regions have been identified in the Aegean and its surrounding area. A mapping of these regions revealed that in many cases there is overlap of adjoining focal regions.

In addition to the shallow $(\mathrm{h} \leq 60 \mathrm{~km})$ focal regions defined in the present work, there have been also defined in the southern part of the Aegean area four (4) focal regions of intermediate focal depth $(60 \mathrm{~km}<\mathrm{h} \leq 100 \mathrm{~km})$ where very strong destructive earthquakes have occurred $\left(\mathrm{D}_{1}, \mathrm{D}_{2}, \mathrm{D}_{3}, \mathrm{D}_{4}\right.$ in fig. 6.6 of Papazachos and Papazachou, 2003). Available information for these four focal regions is given in table (1) with code numbers $152,153,154$ and 155 whereas data completeness is given by relations (1) and (13).

\section{Orientations of the Largest Faults and Their Slip Vectors}

The orientation of a seismic fault is defined by its strike, $\xi$ (the angle between the intersection of the fault and horizontal plane with the north direction), and by its dip, $\delta$ (the angle between the intersection of the fault plane and the normal to the fault strike vertical plane and the horizontal projection of this intersection). The slip vector, which shows the slip direction of the hanging wall of the fault, is determined by the rake, $\lambda$ (the angle between the slip vector and the strike direction of the fault) and defines the kind of faulting (normal, thrust, strike-slip dextral or strike-slip sinistral).

To define the strike, $\xi$, the dip, $\delta$, and the rake, $\lambda$, for the main fault of a focal region, i.e. the fault where the largest earthquake in this region has occurred, all reliable fault plane solutions which are available for earthquakes located in the corresponding focal region have been used to determine a typical solution by a method proposed by Papazachos and Kiratzi (1992). This typical fault plane solution is adopted as the fault plane solution for the corresponding main fault.

In many cases we encountered the following situation: the typical fault plane solution for a certain focal region, (B), was of the same type with the solution determined earlier for an adjoining focal region, (A), where the magnitude of the largest earthquake was larger than the magnitude of the largest earthquake in region (B). Taking this fact into account we incorporated all data (earthquakes and fault plane solutions) of the region (B) in the region (A) in the cases of significant overlap of both regions. This resulted in 151 typical fault plane solutions. We then compared the values of strike, dip and rake of these solutions with the corresponding values determined for the major faults 
in the Aegean and surrounding area (Papazachos et al., 2001). We found that the values of the attributes (strike, dip, rake) of the majority of these 151 typical fault plane solutions were close to those of Papazachos et al. (2001) which were based on a large amount of well documented seismological and geological data. For this reason, the information on the strike, $\xi$, dip, $\delta$, and rake, $\lambda$, listed in table (1) for almost all typical fault plane solutions comes from the work of Papazachos et al. (2001). In the same table corresponding symbols are used to denote thrust faults in the subduction area (TS), thrust faults in the continental area (TC), normal faults (N), strike-slip dextral faults (SD) and strike-slip sinistral faults (SS). Figure (1) shows on a map of the Aegean area these 151 main faults denoted with the corresponding symbols. The length of the symbols used to denote these faults is proportional to the length calculated according to the relations presented in the next section whereas the center of each fault coincides with the center of the respective focal region.

\section{Length, Width and Slip of Main Faults}

Several empirical relations between the basic fault parameters (fault length, width, fault slip) and the magnitude of the corresponding earthquake have been proposed (Kanamori and Anderson 1975, Bonilla et al. 1984, Wesnousky 1986, Wells and Coppersmith 1994, Smith and Stock 2004, Papazachos and Papazachou 2003, among others). There are, however, differences among these relations which stem from uncertainties of the data used. Papazachos et al. (2004) used a considerable number of published reliable global data which are homogeneous (fault parameters estimated by the same method, earthquake magnitudes in the same scale), fairly accurate (accurate fault parameters, magnitudes) to relate the fault length, $\mathrm{L}$ (in $\mathrm{km}$ ) and the fault width, $\mathrm{w}$ (in $\mathrm{km}$ ) of the fault as well as the mean slip (displacement) of a fault, $\mathrm{u}(\mathrm{in} \mathrm{cm}$ ) with the moment magnitude, $\mathrm{M}$ for three kinds of faults (strike-slip faults, dip-slip continental faults and dip-slip faults in subduction regions). These relations are as follows:

(a) Strike-slip faults $\left(\mathrm{F}_{1}\right)$

$$
\begin{aligned}
& \log \mathrm{L}=0.59 \mathrm{M}-2.30, \\
& \log \mathrm{w}=0.23 \mathrm{M}-0.49, \\
& \log \mathrm{u}=0.68 \mathrm{M}-2.59,
\end{aligned}
$$

which hold for $6.0 \leq \mathrm{M} \leq 8.0$,

(b) Dip-slip continental faults $\left(\mathrm{F}_{2}\right)$

$$
\begin{aligned}
& \log \mathrm{L}=0.50 \mathrm{M}-1.86, \\
& \log \mathrm{W}=0.28 \mathrm{M}-0.70, \\
& \log \mathrm{u}=0.72 \mathrm{M}-2.82,
\end{aligned}
$$

which hold for $6.0 \leq \mathrm{M} \leq 7.5$ and for both normal and thrust faults in continental regions,

(c) Dip-slip faults in subduction regions $\left(\mathrm{F}_{3}\right)$

$$
\begin{aligned}
& \log \mathrm{L}=0.55 \mathrm{M}-2.19, \\
& \log \mathrm{W}=0.31 \mathrm{M}-0.63, \\
& \log \mathrm{u}=0.64 \mathrm{M}-2.56,
\end{aligned}
$$

which hold for $6.7 \leq \mathrm{M} \leq 9.2$. These relations have been used to calculate the three parameters for each 


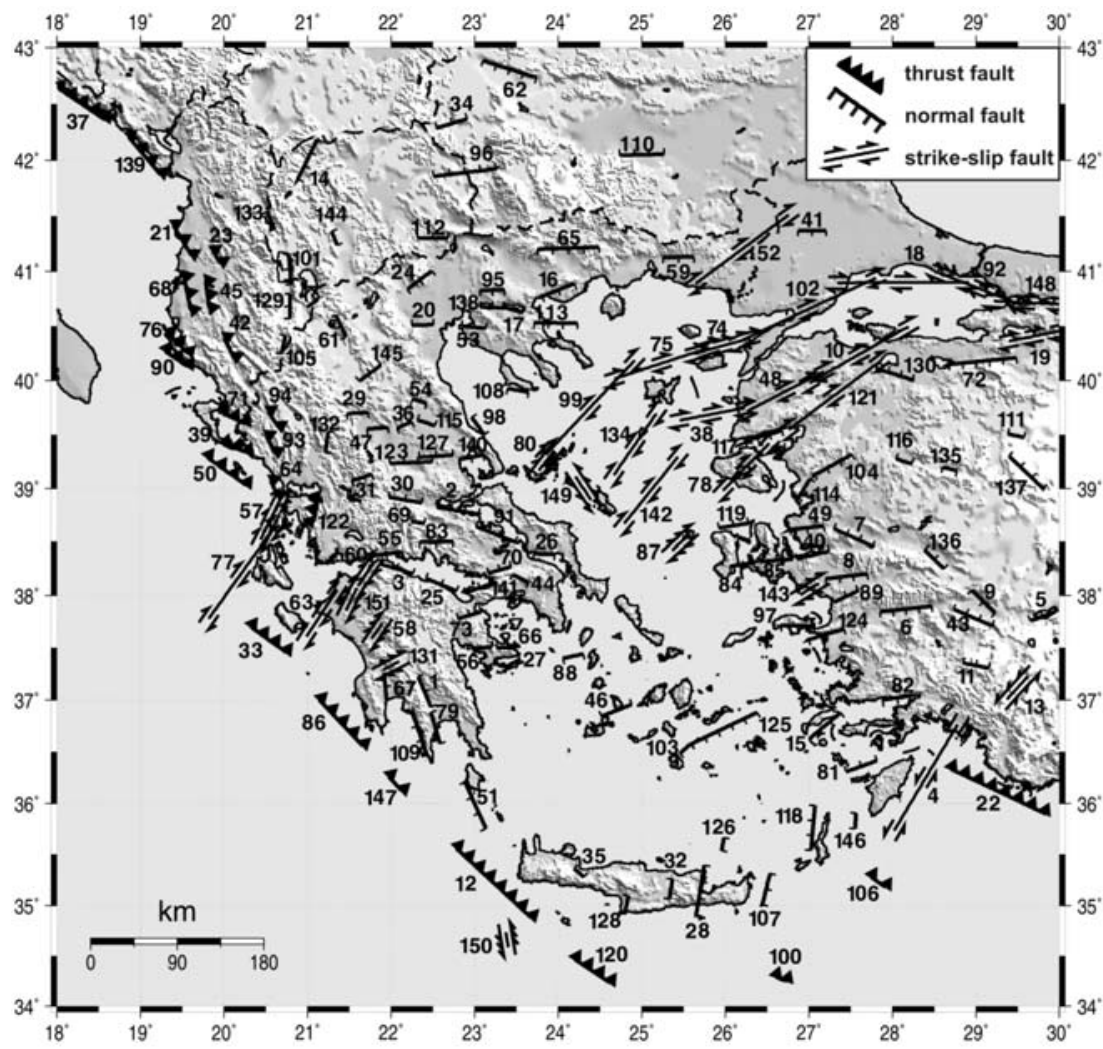

Fig. 1: The main seismic faults of shallow $(h \leq 60 \mathrm{~km})$ mainshocks in the Aegean area. The center of each fault coincides with the center of the respective focal region whereas its length has been determined by a set of relationships appropriate for the kind of each fault. The numbers correspond to the code numbers listed in table (1).

of the shallow main faults defined in the present work for the Aegean area. In table (1) the corresponding symbols (F1, F2, F3) are shown to denote the kind of each of the shallow main faults of the Aegean area determined in the present work. Thus, by applying the proper set of relations $(3,4,5)$ the corresponding values of $\mathrm{L}, \mathrm{w}, \mathrm{u}$, have been calculated by using the corresponding magnitude, $\mathrm{M}$, and these values are listed in table (1).

\section{Declustering of Data}

Declustering of data means the use of the original catalogue described in section (2) to create a catalogue that includes mainshocks only. Earthquakes of the original catalogue included in a focal region are spatially and temporally clustered and a procedure must be applied to make a temporal declustering of these earthquakes by excluding associated shocks. Such shocks are the ones preceding (preshocks) or following (postshocks) each mainshock in the focal region. Such declustering is performed in the present work by assuming that the preshock period is equal to the postshock period and independent of the mainshock magnitude. As a measure of clustering the ratio, $C_{v}=\sigma / T$, is used where $\mathrm{T}$ is the mean repeat time of the earthquakes of the cluster and $\sigma$ is its standard deviation (Kagan and Jackson, 1991). $\mathrm{C}_{\mathrm{v}}$ takes a value: equal to 1 for Poissonian distribution, larger than 1 for clustered shocks, equal to zero for periodic generation of shocks and an intermediate value (e.g. $\left.\mathrm{C}_{\mathrm{v}}=0.5\right)$ for 


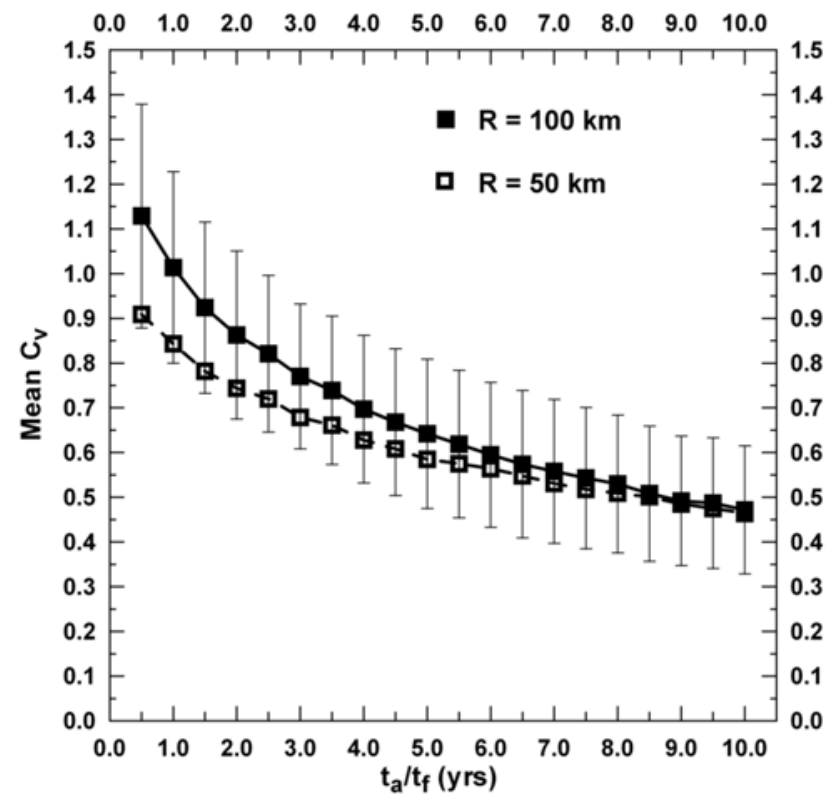

Fig. 2: Variation of the average value of the ratio $C_{v}(=\sigma / T)$ with the duration of the time windows (in years) before $\left(\mathrm{t}_{\mathrm{f}}\right)$ and after $\left(\mathrm{t}_{\mathrm{a}}\right)$ a mainshock. All earthquakes that occurred in these time windows are considered as associated shocks (preshocks and postshocks, see text for explanation).

quasi-periodic behavior as are the earthquakes which follow the time predictable model. Thus, the optimum time duration of associated shocks (preshocks, postshocks) for which a proper declustering is obtained is that one for which $\mathrm{C}_{\mathrm{v}}$ takes its smallest value. To define this optimum time duration the following procedure was followed:

By using a circle with center coinciding with the center, E, of each focal region and a constant radius, $R$ (e.g. $R=50 \mathrm{~km}$ ), the sample of all earthquakes which occurred during the instrumental period $(\mathrm{M} \geq 5.2,1911-2008)$ and have epicenters within the circle is defined. Considering the largest earthquake of the sample as the largest mainshock we excluded from the initial sample all shocks which occurred within a time window \pm 0.5 yrs from the origin time of the largest mainshock. This procedure is repeated on the remaining sample and so on till all mainshocks of the region are defined. If the number of these mainshocks is larger than three $(n \geq 3)$, the mean return period, $T$, its standard deviation, $\sigma$, and their ratio, $C_{v}$, for $\Delta t= \pm 0.5$ yrs are defined. This is repeated for several time windows $(0.5,1.0, \ldots, 9.5,10.0 \mathrm{yrs})$ and the corresponding pairs of time windows and $\mathrm{C}_{\mathrm{v}}$ are formed. This procedure is followed for the mainshocks occurred in the instrumental period in each one of the regions with centers, $\mathrm{E}$, and the same radius (e.g. $\mathrm{R}=50 \mathrm{~km}$ ) and the average $\mathrm{C}_{\mathrm{v}, \text { ave }}$ value is calculated for each of the defined time windows. Figure (2) is a plot of $C_{v, \text { ave }}$ as a function of $\Delta t$ for $R=50$ $\mathrm{km}$ and another such plot for $\mathrm{R}=100 \mathrm{~km}$. It is obvious that in both plots the value of $\mathrm{C}_{\mathrm{v}, \text { ave }}$ decreases with time up to $\Delta \mathrm{t}=8.5 \mathrm{yrs}$ where $\mathrm{C}_{\mathrm{v}, \mathrm{ave}}=0.50$ and that for larger time windows $\mathrm{C}_{\mathrm{v}, \text { ave }}$ is practically constant. It is, therefore, concluded that declustering must be made in each originally defined focal region by excluding preshocks and postshocks which occurred in a time window \pm 8.5 yrs from each mainshock of the focal region. It is also concluded that $\sigma=0.50 \cdot \mathrm{T}$, which is an important result used in the next section to define completeness of the historical data. 


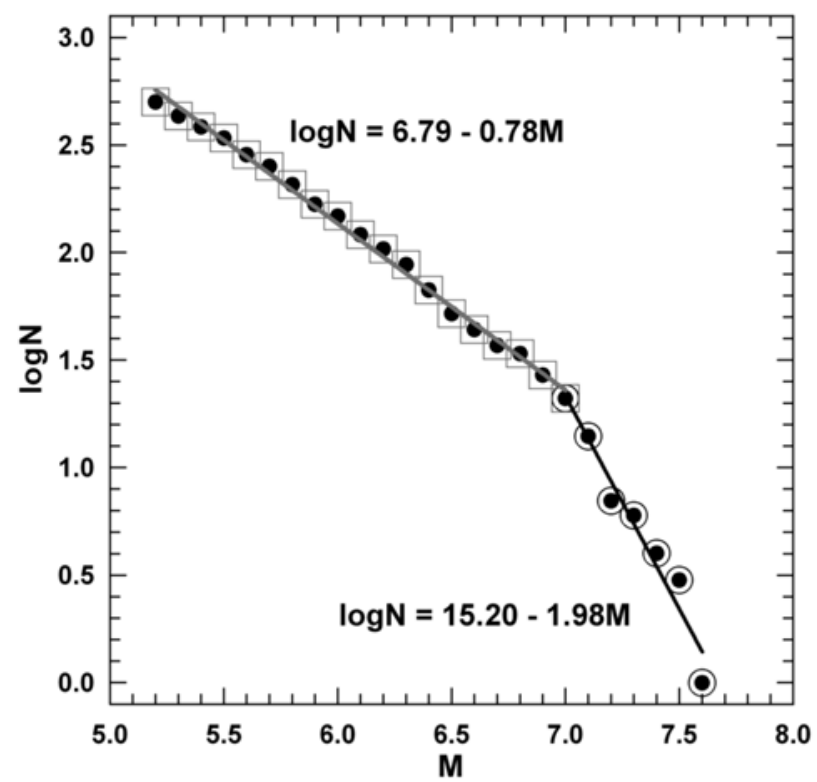

Fig. 3: The cumulative frequency-magnitude distribution of the shallow mainshocks with $M \geq 5.2$ which occurred in the Aegean area during 1911-2008.

To decluster the initial sample of earthquakes included in each focal region and define the mainshocks of this region, the following procedure is applied: The largest earthquake of the focal region is considered as mainshock and all shocks of the region which occurred within a time window \pm 8.5 yrs from the origin time of the largest mainshock are excluded. The same procedure is applied on the remaining sample to determine the second largest mainshock, etc. till all mainshocks of the focal region are defined. Thus, the mainshocks of all focal regions form the catalogue of mainshocks of the whole Aegean area.

Figure (3) shows the cumulative frequency-magnitude distribution of all mainshocks of the Aegean area which occurred during the instrumental period (1.1.1911-31.12.2008). The data are fitted in the least squares' sense by the following relations:

with

$$
\begin{gathered}
\log \mathrm{N}=\mathrm{a}_{1}-\mathrm{b}_{1} \mathrm{M}, \text { for } 5.2 \leq \mathrm{M}<7.0 \\
\log \mathrm{N}=\mathrm{a}_{2}-\mathrm{b}_{2} \mathrm{M}, \text { for } \mathrm{M} \geq 7.0 \\
\mathrm{~b}_{1}=0.78, \mathrm{a}_{1}=6.79, \mathrm{a}_{1 \mathrm{r}}=4.80 \\
\mathrm{~b}_{2}=1.98, \mathrm{a}_{2}=15.20, \mathrm{a}_{2 \mathrm{r}}=13.21
\end{gathered}
$$

Parameters $\mathrm{a}_{1 \mathrm{r}}$ and $\mathrm{a}_{2 \mathrm{r}}$ are the reduced values of $\mathrm{a}_{1}$ and $\mathrm{a}_{2}$ to one year. The parameter $\mathrm{a}_{2}$ can be also calculated by the relation:

$$
\mathrm{a}_{2}=\mathrm{a}_{1}+7.0\left(\mathrm{~b}_{2}-\mathrm{b}_{1}\right)
$$

Then, the mean return periods for the mainshocks are given by the relations:

$$
\begin{aligned}
& \mathrm{T}=10^{\mathrm{b}_{1} \mathrm{M}-\mathrm{a}_{1} \mathrm{r}} \text { for } \mathrm{M}<7.0 \\
& \mathrm{~T}=10^{\mathrm{b}_{2} \mathrm{M}-\mathrm{a}_{2} \mathrm{r}} \text { for } \mathrm{M} \geq 7.0
\end{aligned}
$$


The values of the scaling parameters $\left(b_{1}=0.78, b_{2}=1.98\right)$ can be considered constant and holding for all focal regions. For this reason, if instrumental data for mainshocks with $\mathrm{M} \leq 7.0$ are available for a particular focal region, relation (6) can be used to calculate $a_{1}$ and relation (10) to calculate $a_{2}$ for this region. Then, relation (11) or relation (12) can be used to calculate the mean return period.

\section{Completeness of Historical Mainshocks}

Another basic requirement of any historical earthquake catalogue, in addition to the homogeneity in the magnitude determination, is the assessment of its completeness, i.e. the assessment of the minimum magnitude above which the catalogue is considered to be fully reported. Traditional methods of estimating completeness of an earthquake catalogue are the frequency-magnitude and the timemagnitude distributions. Both these procedures led to the conclusion that earthquakes in the whole Aegean area investigated in the present work $\left(34^{\circ} \mathrm{N}-43^{\circ} \mathrm{N}, 18^{\circ} \mathrm{E}-30^{\circ} \mathrm{E}\right)$ are complete for the period and magnitude range defined by relation (1) and by the relation:

$\mathrm{M} \geq 6.5,1845-2008$

Furthermore, completeness is defined for historical mainshocks with $\mathrm{M}^{3} 6.5$ in each circular region $(\mathrm{E}, \mathrm{R}=100 \mathrm{~km}$ ) where $\mathrm{E}$ are the centers of the 151 shallow focal regions. For this purpose we used the information for the mainshocks that occurred during the instrumental period (1911-2008) and are located within the circle $(E, R=100 \mathrm{~km})$ to determine the value $a_{1}$ by the relation (6) assuming $b_{1}=0.78$. Then, we used these two values and $b_{2}=1.98$ to calculate $a_{2}$ by the relation (10). After reducing $\mathrm{a}_{1}$ and $\mathrm{a}_{2}$ to one year $\left(\mathrm{a}_{1 \mathrm{r}}, \mathrm{a}_{2 \mathrm{r}}\right)$ we can use the relations $(11,12)$ to calculate mean return periods for any historical earthquake. For example, we considered all mainshocks which are located within the circle $(\mathrm{E}, \mathrm{R}=100 \mathrm{~km})$ and for each of them we calculated its mean return period, $\mathrm{T}$, by applying relation (11) or (12) according to its magnitude. Then, the time period $\mathrm{T}^{*}=\mathrm{T}+2 \cdot \sigma\left(\right.$ with $\sigma=\mathrm{C}_{\mathrm{v}}$ $\cdot \mathrm{T}=0.50 \cdot \mathrm{T})$ is calculated and subtracted from the origin time, $\mathrm{t}_{\mathrm{e}}$, of the earliest strong $(\mathrm{M} \geq 6.0)$ mainshock of the instrumental period to define a time $\mathrm{t}=\mathrm{t}_{\mathrm{e}}-\mathrm{T}^{*}$. If the mainshock occurred after this time, $t$, it is included in the complete data, otherwise it is not. In this way each circular region (E, $\mathrm{R}=100 \mathrm{~km}$ ) includes epicenters of mainshocks which occurred during the instrumental and historical times and form complete samples of mainshocks. Information on the completeness of mainshocks in each focal region is given in table (1).

\section{Conclusions}

The present work aimed at facilitating seismic hazard studies by proposing a methodology of identification of focal regions. Such a region includes the main fault where the largest mainshock occurs, and smaller faults where smaller mainshocks also occur. These focal regions can be considered as spatial clusters of earthquakes. Clustering is usually attributed to foreshocks and mainly to aftershocks but even if these shocks are omitted from the data clustering still prevails, because spatial clustering occurs not only in the rupture zone of a mainshock but also in a broader area where other mainshocks occur.

The proposed methodology is applied in the Aegean area where 155 focal regions and their respective main faults were identified. This number of focal regions can be compared to that of Papazachos et al. (2001) who, using a large amount of seismological (distribution of epicentres, macroseismic information, focal mechanisms) and geological data (surface fault traces, stratigraphic and geomorphological data), determined the properties of 160 faults where the known major $(M \geq 6.0)$ shallow earthquakes have occurred in the Aegean area. Fault dimensions and maximum slip were determined by appropri- 


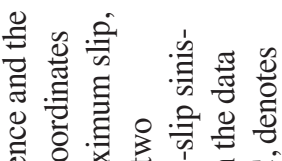

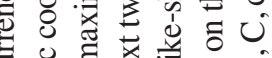

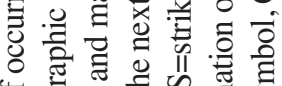
응

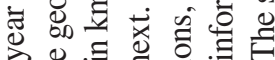
政

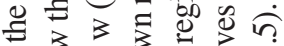

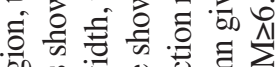

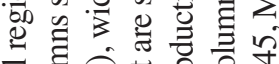

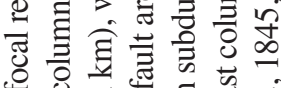

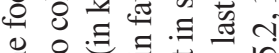

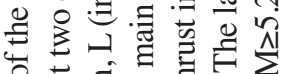

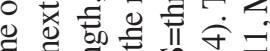
흘 of

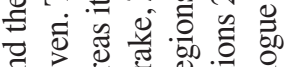

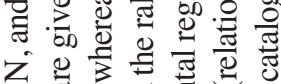
乙. 章.

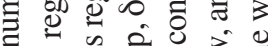

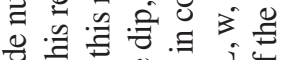
응

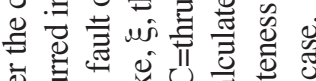

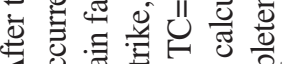
< 8

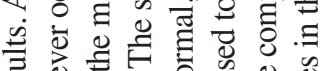

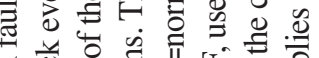

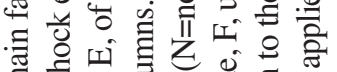
E.

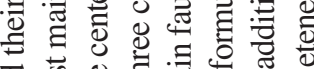

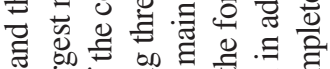

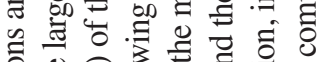

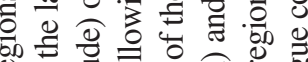
원

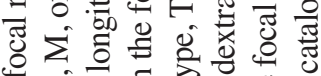
\% $a 5$

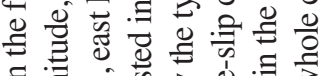

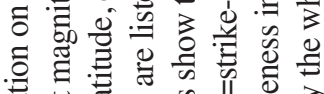

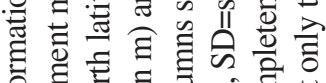

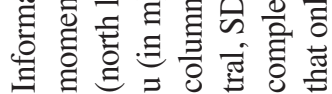

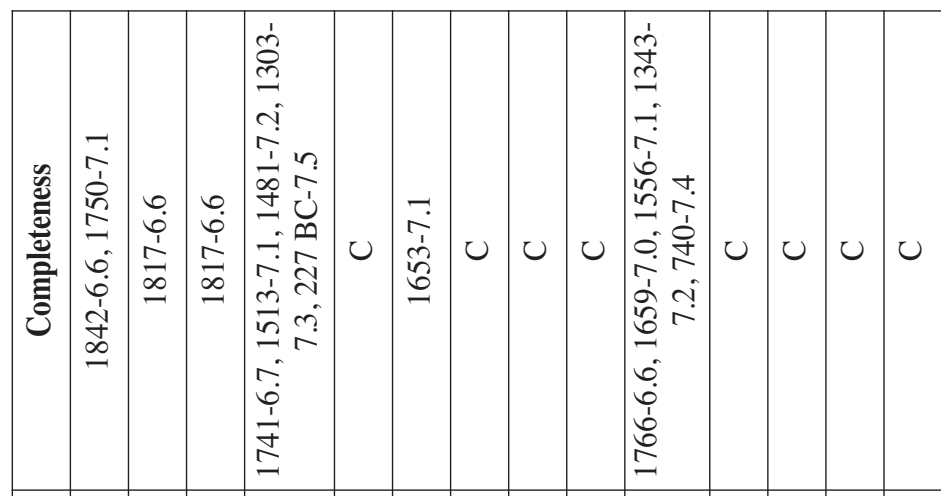

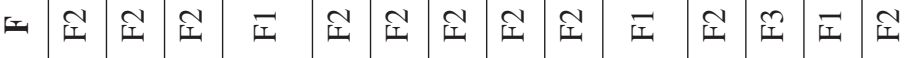

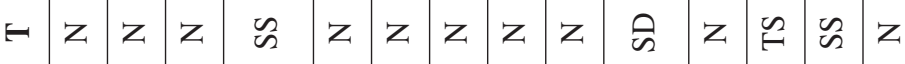

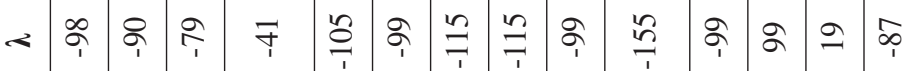
•

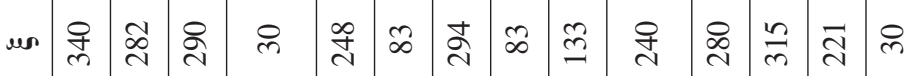

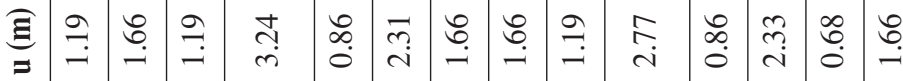

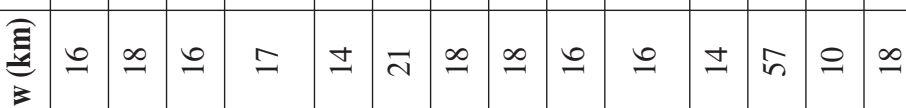

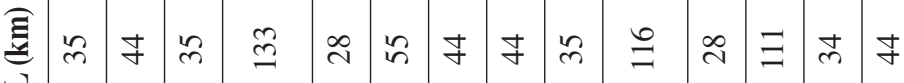

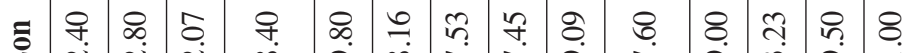

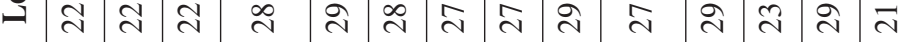
च

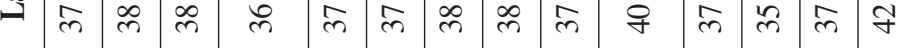

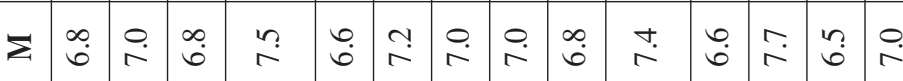
¿

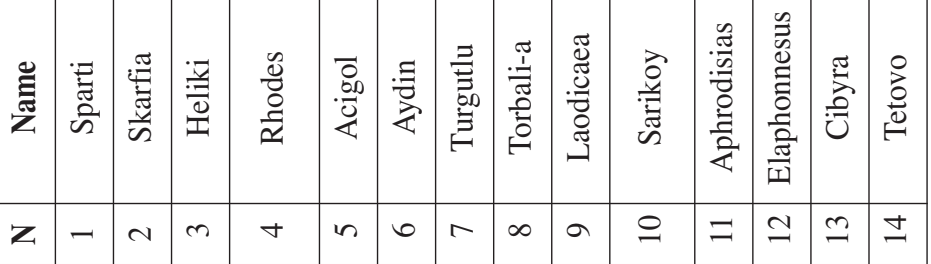




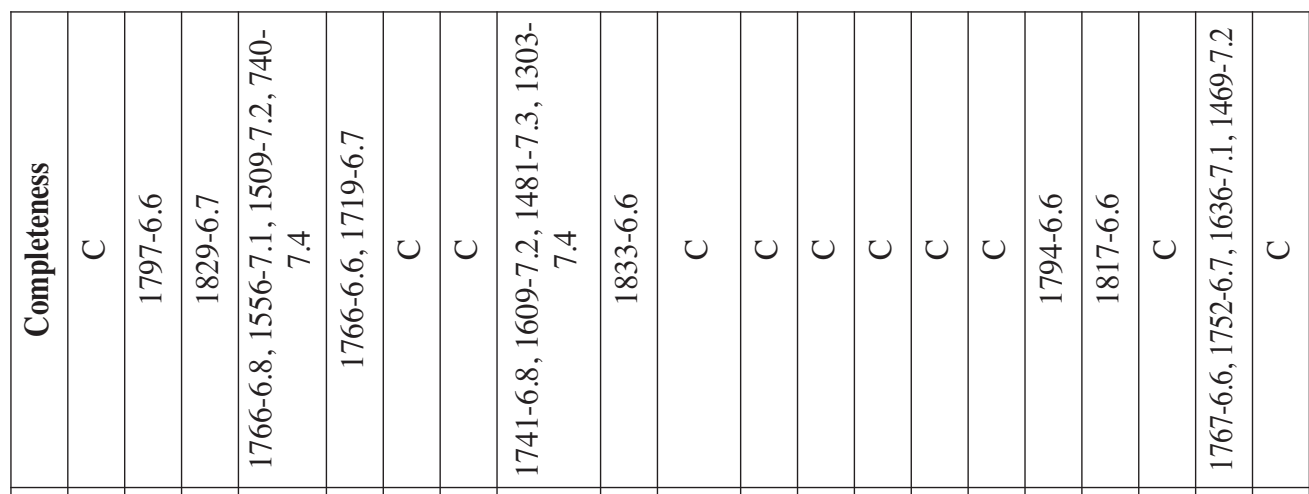

E I I I E

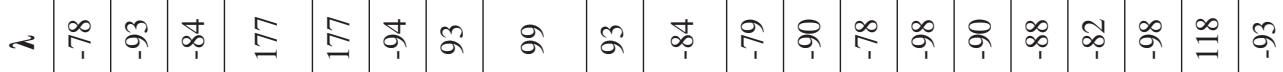

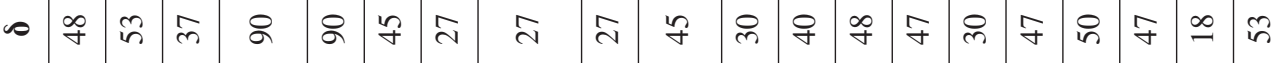
m

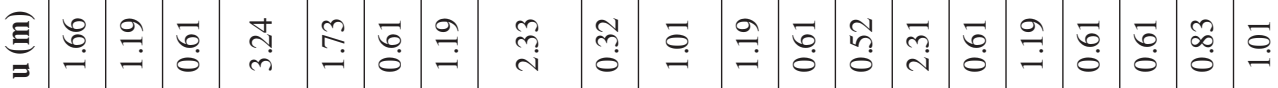

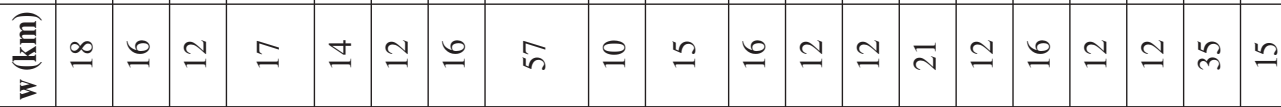

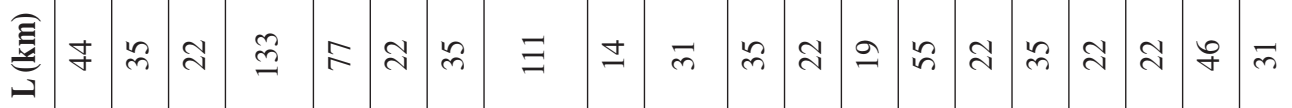

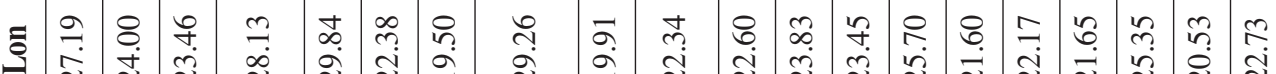
এ

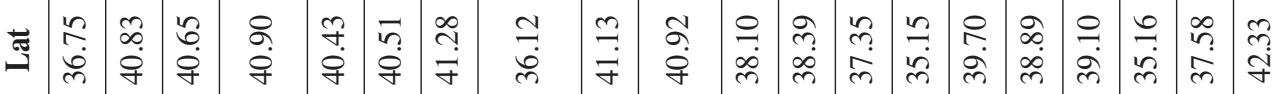

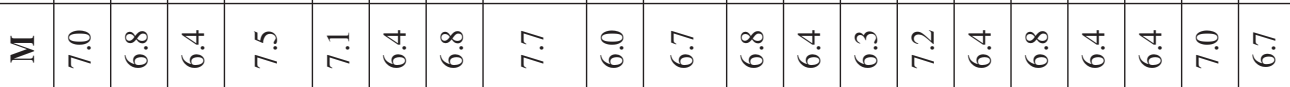

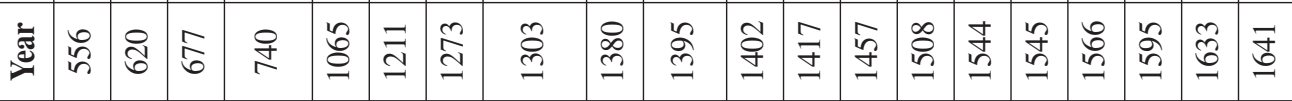

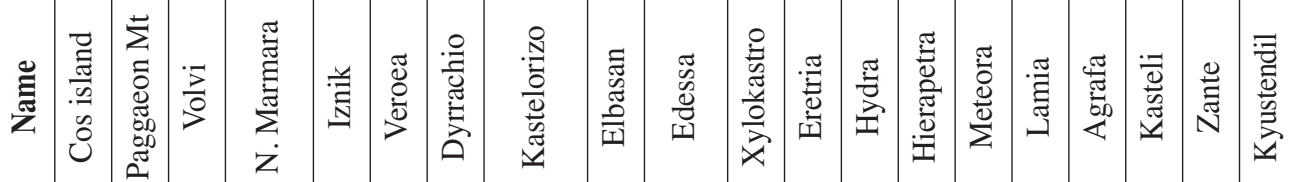
z 


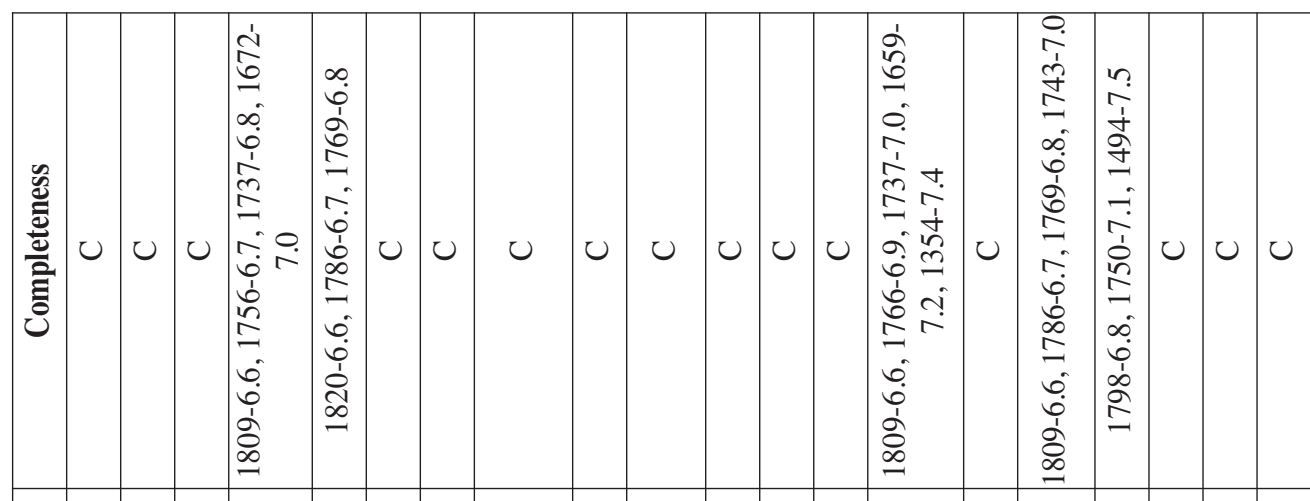

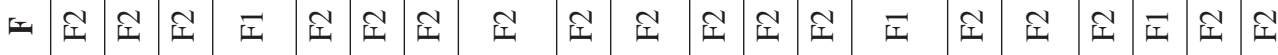

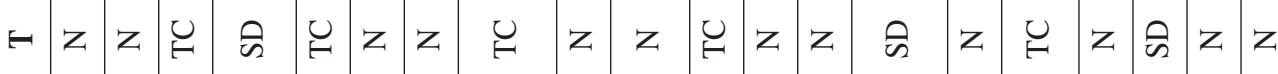
$<$ <舟品

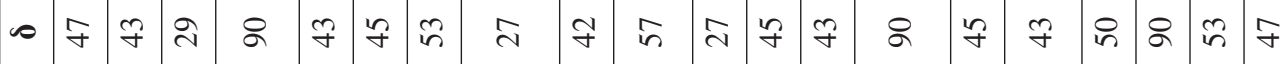

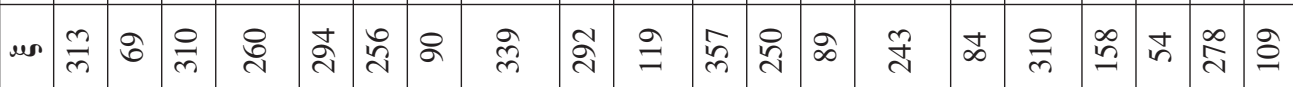

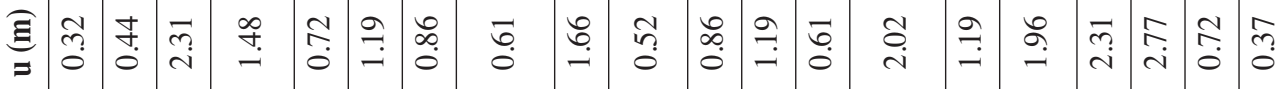

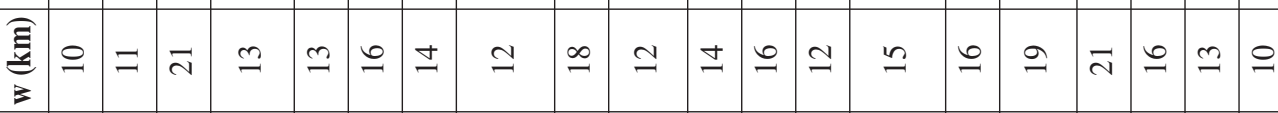

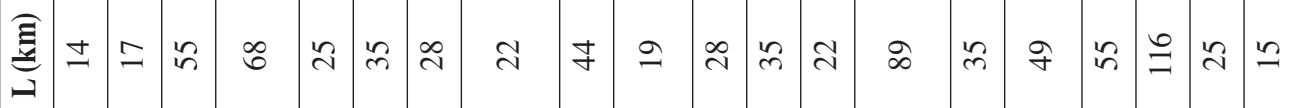
z

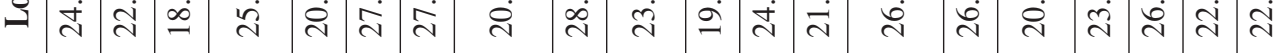

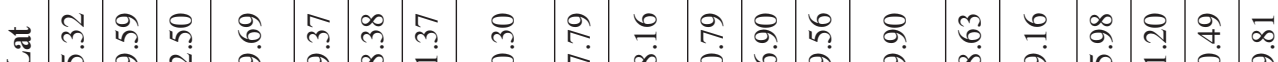

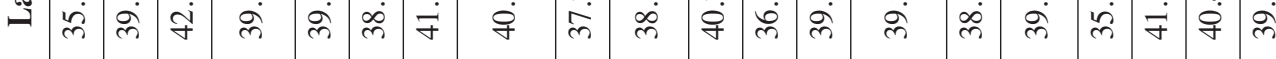

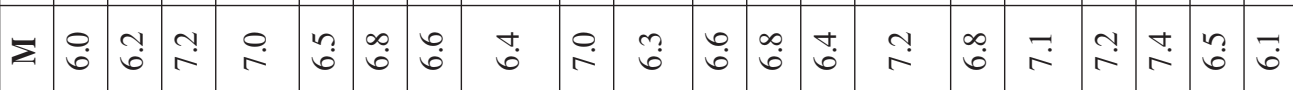
氙

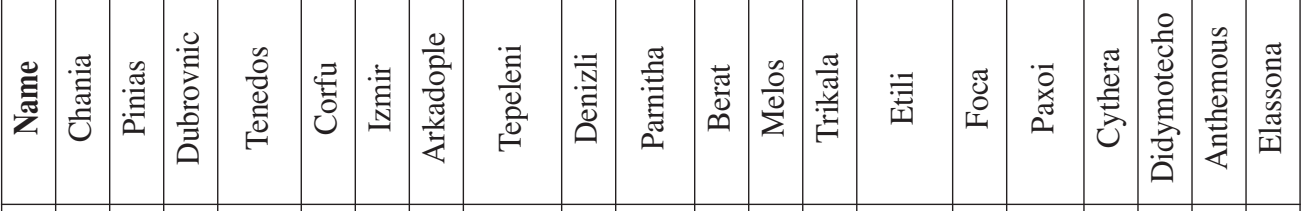

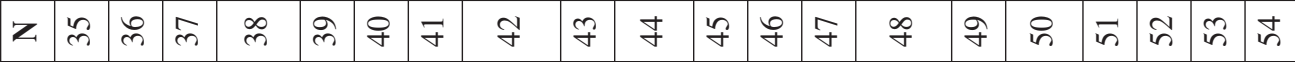




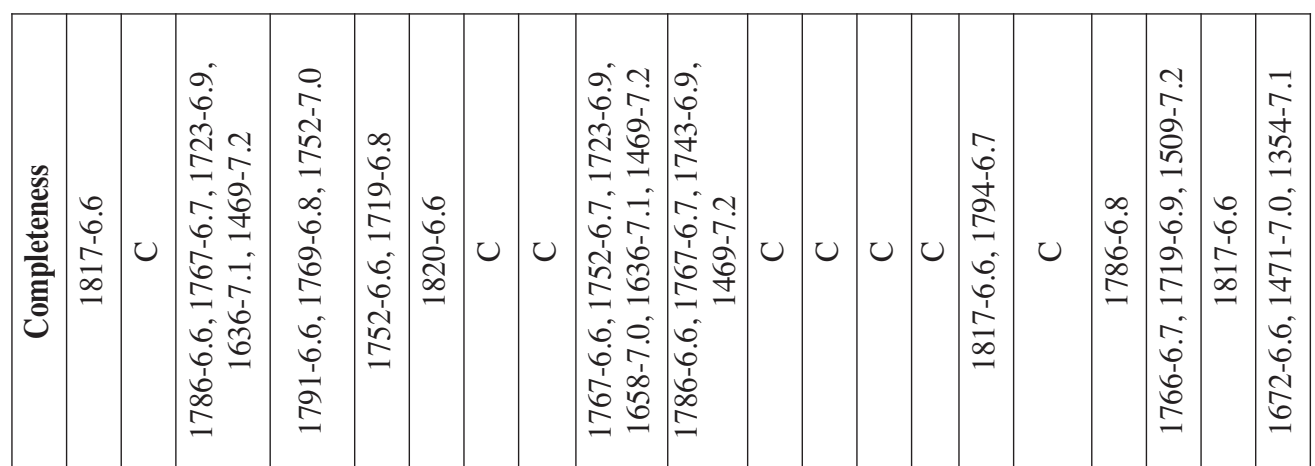

E I I I - $\mathbf{z}$ z

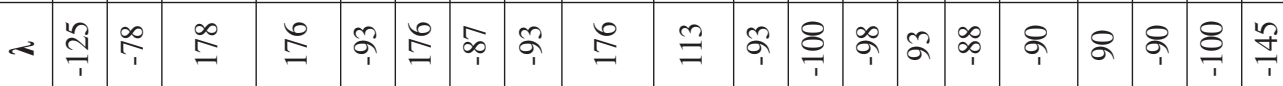

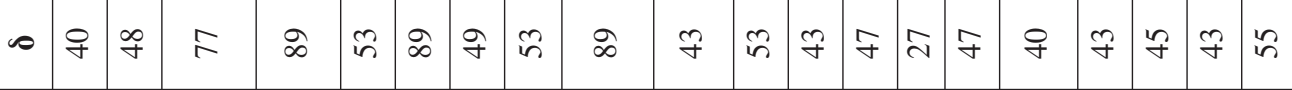
un

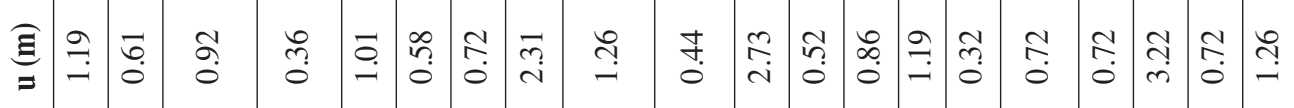

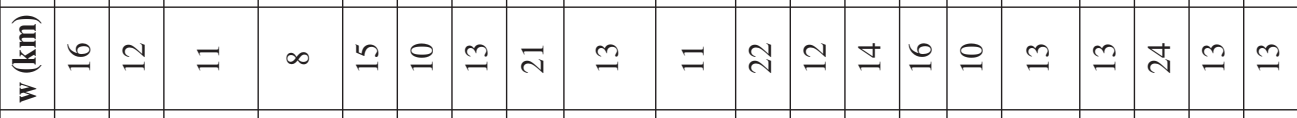

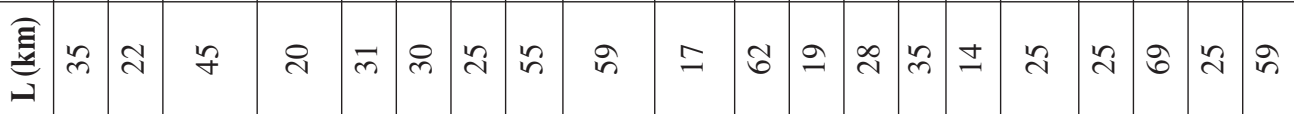
รี

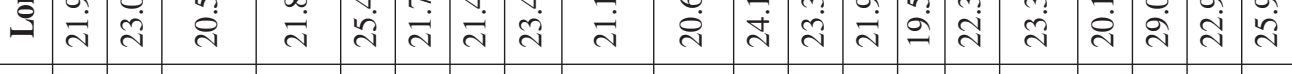
F

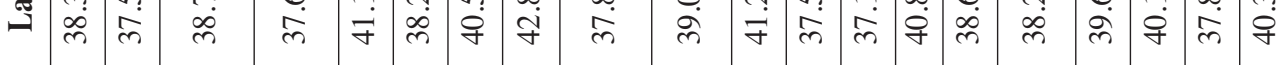

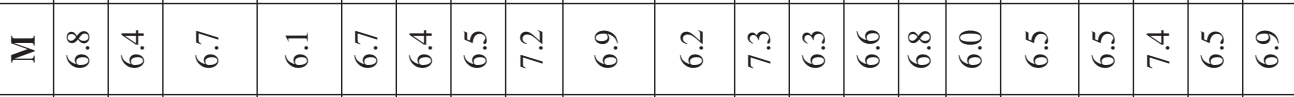

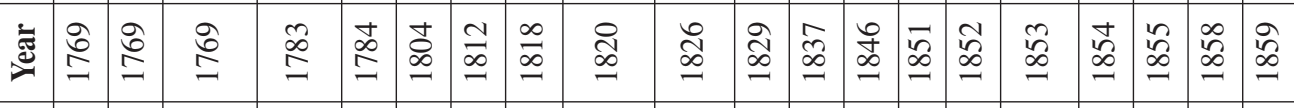

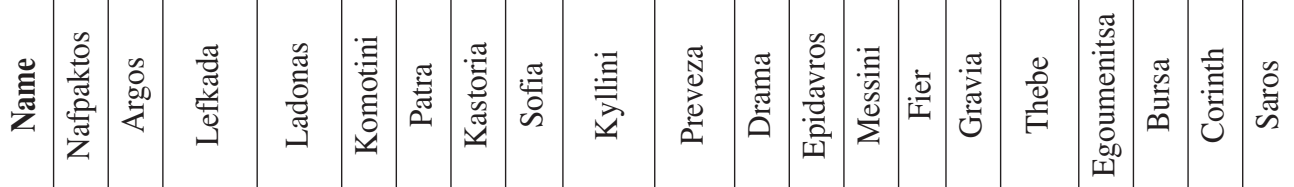

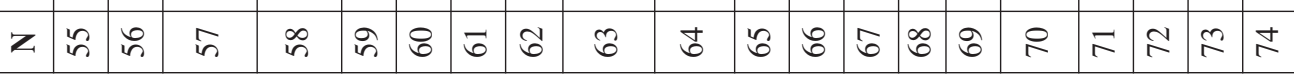




\begin{tabular}{|c|c|c|c|c|c|c|c|c|c|c|c|c|c|c|c|c|c|c|c|c|}
\hline 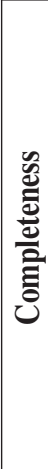 & $\begin{array}{l}7 \\
0 \\
1 \\
2 \\
1 \\
1 \\
0 \\
0 \\
0 \\
0 \\
-1 \\
-1\end{array}$ & $U$ & 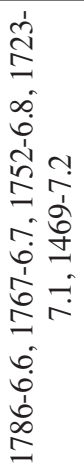 & 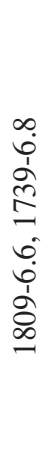 & 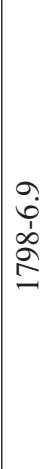 & $\cup$ & $U$ & 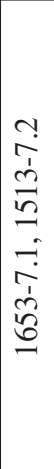 & 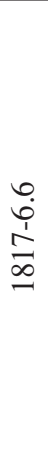 & $\cup$ & $U$ & $\begin{array}{l}\infty \\
\dot{1} \\
\stackrel{1}{=} \\
\infty \\
-1\end{array}$ & $u$ & $U$ & $U$ & $U$ & $U$ & 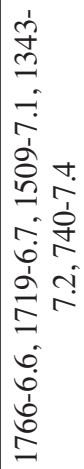 & $\begin{array}{l}0 \\
0 \\
1 \\
1 \\
\infty 1 \\
\infty \\
-1\end{array}$ & 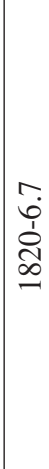 \\
\hline 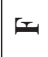 & $\bar{I}$ & I & $\vec{I}$ & $\bar{I}$ & II & $\bar{I}$ & II & II & II & II & II & 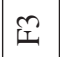 & $\vec{I}$ & II & $\stackrel{N}{I}$ & II & I & $\overline{I I}$ & II & $\stackrel{N}{I}$ \\
\hline 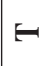 & $\theta$ & $\underset{H}{U}$ & 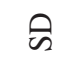 & $\hat{n}$ & Z & $\theta$ & Z & Z & Z & Z & Z & $\tilde{\omega}$ & 会 & z & z & $\circlearrowright$ & Z & ڤ & $\underset{\epsilon}{U}$ & 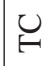 \\
\hline$\alpha$ & $\frac{?}{1}$ & 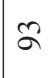 & $\stackrel{\mathbb{I}}{I}$ & 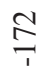 & $\stackrel{\infty}{a}$ & $\stackrel{\cong}{\simeq}$ & $\stackrel{\infty}{\uparrow}$ & के & \& & $\stackrel{n}{=}$ & $\stackrel{n}{7}$ & $\stackrel{0}{\circ}$ & $\frac{n}{n}$ & $\stackrel{\infty}{\uparrow}$ & $\stackrel{n}{7}$ & ๙ & ? & $\frac{n}{n}$ & $\stackrel{n}{=}$ & $\stackrel{\cong}{=}$ \\
\hline$\infty$ & $\infty$ & $\hat{\imath}$ & $n$ & ஓ & ซ & 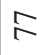 & $\stackrel{\infty}{+}$ & 壬 & f & $\mathscr{\wp}$ & $\stackrel{\wp}{f}$ & กี & $\varpi_{\infty}$ & $\stackrel{\infty}{+}$ & $\stackrel{\wp}{f}$ & $\hat{\sim}$ & 으 & $\stackrel{R}{R}$ & $\mathscr{F}$ & $\mathscr{f}$ \\
\hline en & $\stackrel{n}{n}$ & ๙ & \& & $\stackrel{\curvearrowleft}{\forall}$ & 㝏 & \& & $\stackrel{\overbrace{}}{\sim}$ & ஓ & $\bar{a}$ & న & $\stackrel{\sim}{\circ}$ & กิ & तે & $\infty$ & $\underset{d}{\stackrel{J}{Z}}$ & ᄋి & ১ே & $\stackrel{\varrho}{ }$ & $\hat{m}$ & $\stackrel{n}{m}$ \\
\hline$\underset{\mathrm{\Xi}}{\mathrm{E}}$ & $\hat{n}$ & $\infty$ & $\stackrel{i}{i}$ & $\stackrel{\infty}{\stackrel{\infty}{\sim}}$ & $\stackrel{9}{=}$ & ণ̊. & $\stackrel{9}{=}$ & $\stackrel{9}{=}$ & $\stackrel{9}{=}$ & $\stackrel{N}{\mathfrak{O}}$ & $\stackrel{9}{=}$ & $\stackrel{\overbrace{}}{\nearrow}$ & 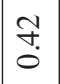 & $\overrightarrow{0}$ & $\begin{array}{l}0 \\
\infty \\
0\end{array}$ & $\begin{array}{l}\circ \\
\infty \\
0\end{array}$ & $\stackrel{0}{\circ}$ & $\underset{\mathrm{C}}{\mathrm{i}}$ & กี & กั \\
\hline$\underbrace{\stackrel{\mathrm{E}}{\mathrm{E}}}_{\mathbb{E}}$ & 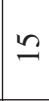 & \pm & 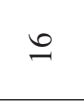 & 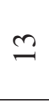 & 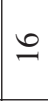 & $a$ & 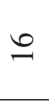 & $\stackrel{0}{-}$ & 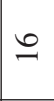 & 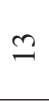 & $\underset{0}{0}$ & $\stackrel{\vartheta}{\forall}$ & a & $\simeq$ & \pm & \pm & $\infty$ & 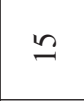 & $\simeq$ & $\simeq$ \\
\hline 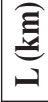 & ฮิ & $\stackrel{\infty}{\sim}$ & $\stackrel{0}{=}$ & $\infty$ & $n$ & $\stackrel{\circ}{\sim}$ & $n$ & $\mathfrak{m}$ & $n$ & $\approx$ & $n$ & $\hat{\sigma}$ & $\ddot{\sim}$ & ป & $\stackrel{\infty}{\sim}$ & $\stackrel{\infty}{\sim}$ & 寸 & ஓे & 9 & $\stackrel{2}{2}$ \\
\hline ڤే & 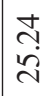 & & సి & 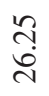 & ñ & 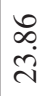 & $\begin{array}{l}\hat{\sigma} \\
\stackrel{\sim}{N}\end{array}$ & $=$ & \begin{tabular}{l}
\multirow{2}{n}{} \\
$\stackrel{\sim}{*}$
\end{tabular} & $\begin{array}{l}\text { กิ } \\
\text { లి }\end{array}$ & $\begin{array}{l}\bar{\sigma} \\
\stackrel{\sim}{ }\end{array}$ & 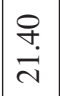 & 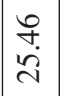 & $\stackrel{\infty}{\underset{J}{\sim}}$ & $\frac{n}{\stackrel{n}{\tau}}$ & & & 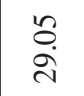 & ڤ̊ & กิ \\
\hline 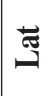 & 足 & 官 & $\begin{array}{l}\text { గ̦ } \\
\infty \\
\infty\end{array}$ & $\begin{array}{l}\text { तે } \\
\text { ळे }\end{array}$ & $\underset{m}{m}$ & مे & $\begin{array}{l}0 \\
\text { గొ } \\
\text { లై }\end{array}$ & $\underset{\text { m. }}{\infty}$ & $\begin{array}{l}0 \\
n \\
\infty \\
m\end{array}$ & $\begin{array}{l}\text { ণे } \\
\infty \\
\infty\end{array}$ & $\begin{array}{l}m \\
\infty \\
\infty \\
m\end{array}$ & 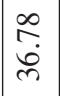 & $\begin{array}{l}a \\
\dot{f} \\
\infty \\
m\end{array}$ & I্ & $\frac{\grave{n}}{\sigma}$ & $\begin{array}{l}\text { ก̦ } \\
\text { P }\end{array}$ & $\begin{array}{l}n \\
\infty \\
\infty \\
m\end{array}$ & $\begin{array}{l}\dot{\$} \\
\infty \\
\dot{+}\end{array}$ & $\begin{array}{l}\vec{\gamma} \\
\stackrel{\rho}{\sigma}\end{array}$ & $\begin{array}{l}\text { ț } \\
\stackrel{\text { mे }}{ }\end{array}$ \\
\hline$\Sigma$ & $\dddot{n}$ & 它 & $\underset{r}{+}$ & $\stackrel{0}{\circ}$ & 我 & n? & $\overbrace{0}^{\infty}$ & & $\underset{0}{\infty}$ & $\tilde{\sigma}$ & $\overbrace{0}^{\infty}$ & $\stackrel{n}{r}$ & ஸु & ẗ & ర) & $\underset{0}{0}$ & $\stackrel{\circ}{\circ}$ & $\stackrel{N}{N}$ & ?ֶ. & nె. \\
\hline$\ddot{\Xi}$ & む্ & $\underline{0}$ & $\underset{0}{0}$ & $\infty$ & ڤ్ & $\begin{array}{l}\infty \\
\infty \\
\infty\end{array}$ & જે & $\begin{array}{l}\hat{\delta} \\
\infty\end{array}$ & $\underset{\infty}{\stackrel{\infty}{\infty}}$ & $\begin{array}{l}\infty \\
\infty \\
\infty\end{array}$ & $\begin{array}{l}\infty \\
\infty\end{array}$ & $\begin{array}{l}\infty \\
\infty \\
\infty \\
-1\end{array}$ & $\stackrel{\circ}{\stackrel{一}{-}}$ & $\vec{\infty}$ & $\stackrel{2}{\infty}$ & $\stackrel{\infty}{\infty}$ & $\stackrel{+}{\infty}$ & $\stackrel{+}{\infty}$ & $\stackrel{2}{\infty}$ & $\stackrel{\infty}{\infty}$ \\
\hline $\begin{array}{l}\text { E } \\
\text { Z } \\
\text { Z }\end{array}$ & 苍 & $\frac{\pi}{0}$ & $\begin{array}{l}\frac{\pi}{0} \\
\frac{0}{\pi} \\
\frac{\pi}{2} \\
\frac{2}{0}\end{array}$ & 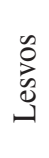 & 荵 & $\begin{array}{l}0 \\
0 \\
0 \\
0 \\
0 \\
0 \\
0 \\
\text { \& }\end{array}$ & $\underset{\sim}{\stackrel{\Xi}{二}}$ & 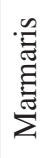 & $\begin{array}{l}\overline{0} \\
\frac{0}{0} \\
\stackrel{0}{0}\end{array}$ & $\begin{array}{l}\stackrel{0}{ٍ} \\
\dot{U} \\
\dot{z}\end{array}$ & $\frac{\pi}{5}$ & 尝 & 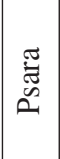 & 总 & 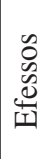 & 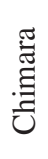 & 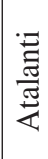 & 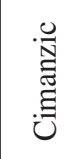 & 丞 & $\begin{array}{l}\text { 莧 } \\
\text { 壳 }\end{array}$ \\
\hline Z & 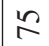 & $?$ & $\hat{\imath}$ & ฉ & 2 & 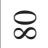 & $\vec{\infty}$ & ๙ & $\hat{6}$ & ஓ & $\mathscr{\infty}$ & $\infty$ & $\infty$ & $\infty$ & ஓ & ৪ & $\bar{a}$ & สু & ๙2 & t \\
\hline
\end{tabular}




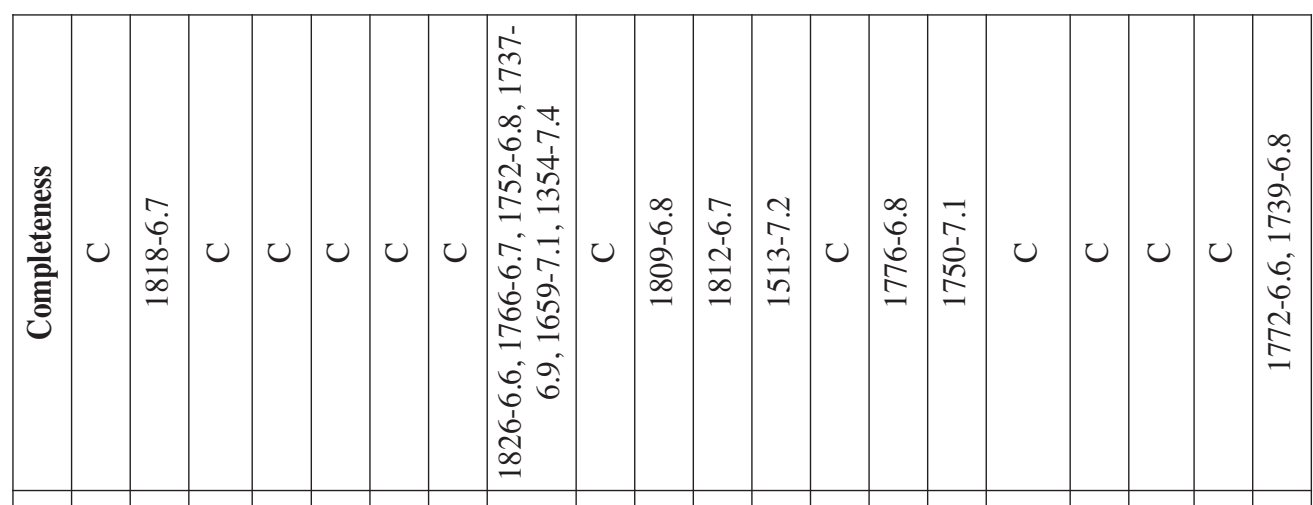

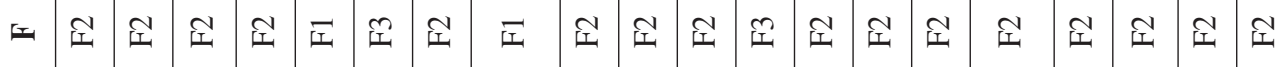
E

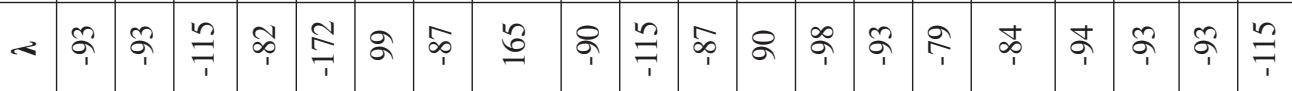

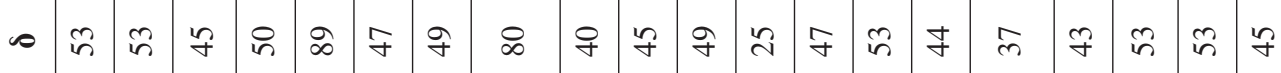
m

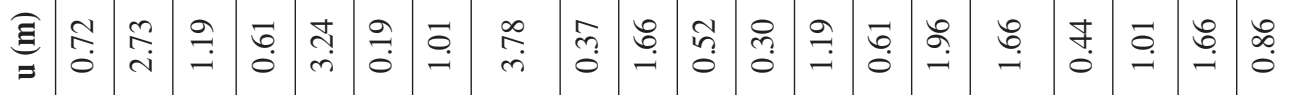

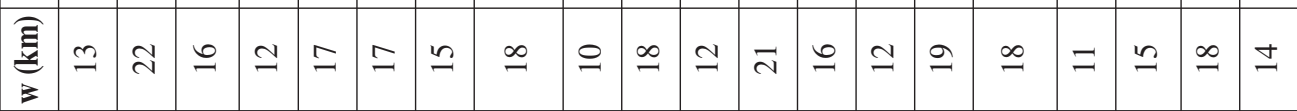

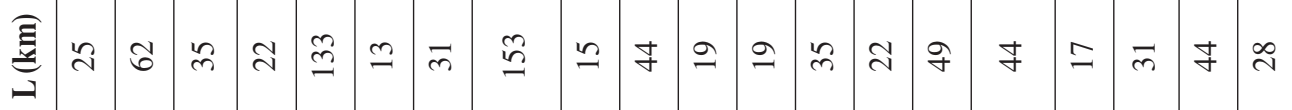

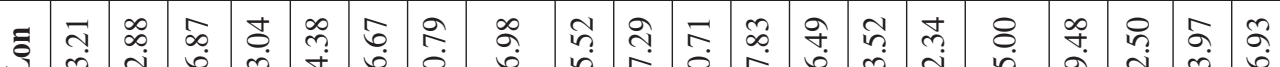
এ ‡

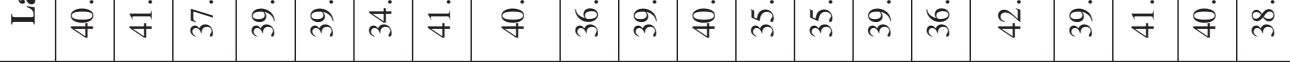

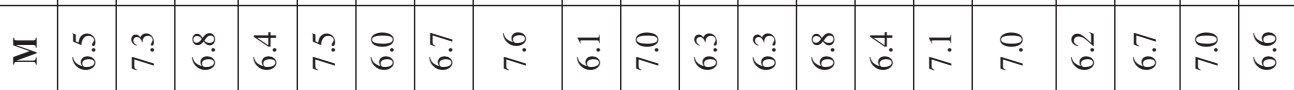
‡્ઇ

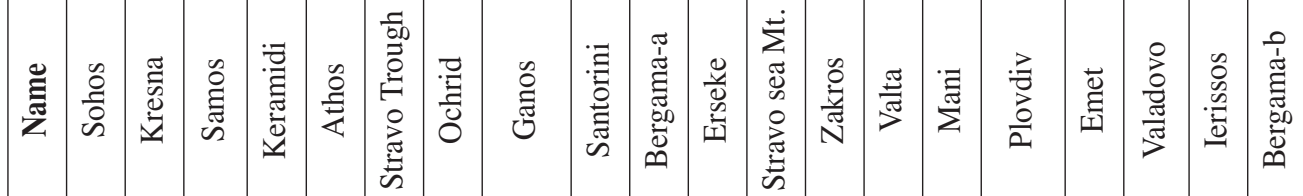
z 


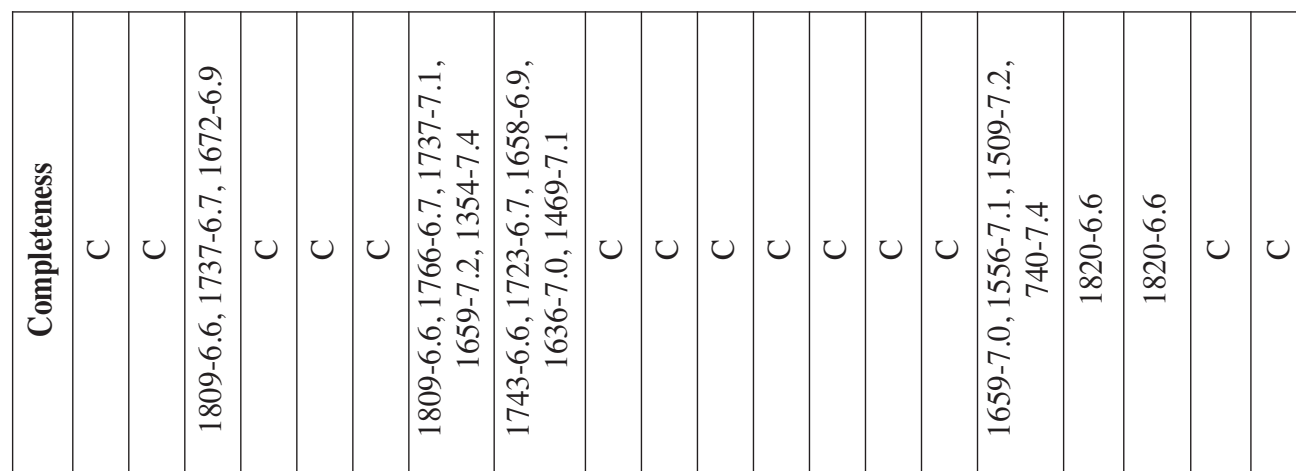

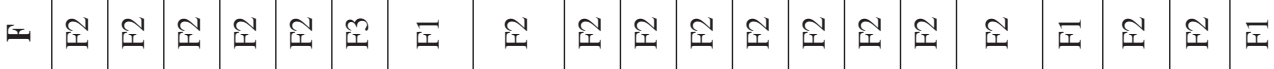
H z z z z z

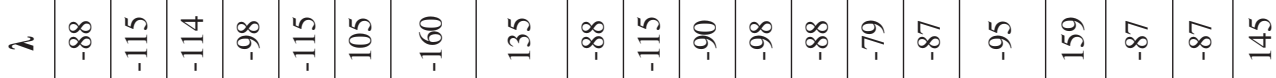

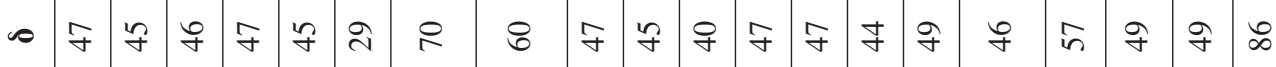

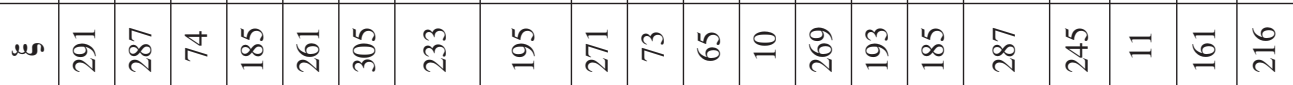
司

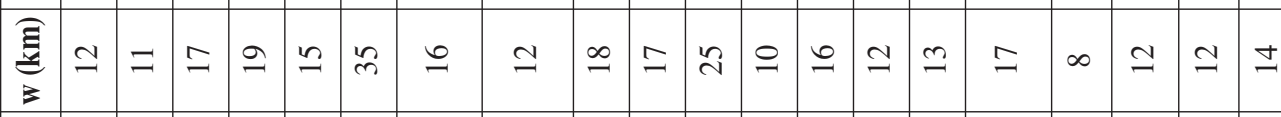

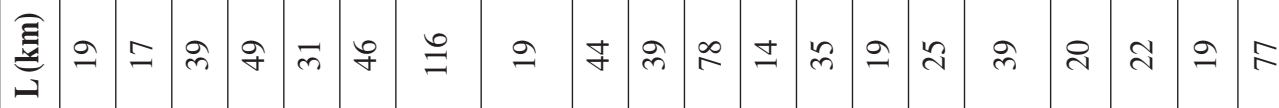

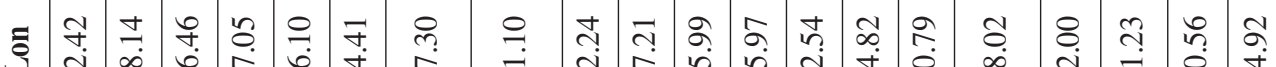

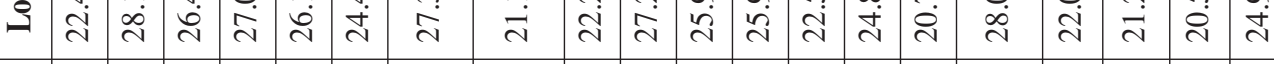

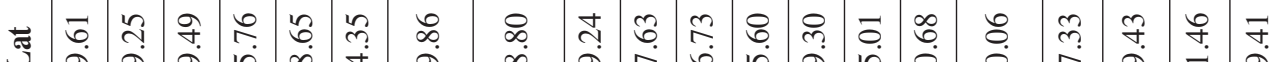

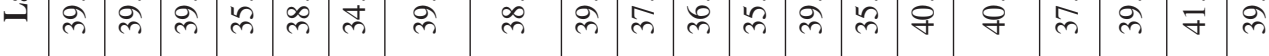
$\Sigma$ г

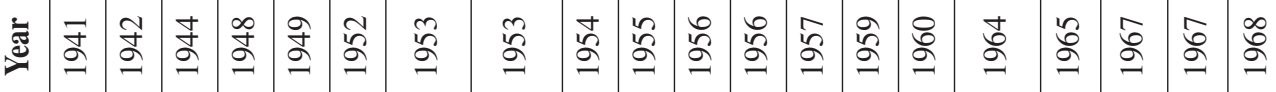

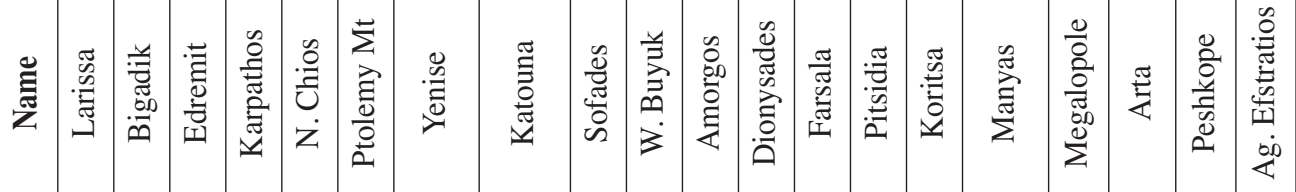

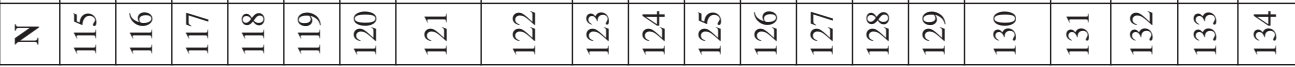




\begin{tabular}{|c|c|c|c|c|c|c|c|c|c|c|c|c|c|c|c|c|c|c|c|c|c|}
\hline 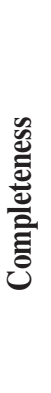 & $U$ & $U$ & $U$ & 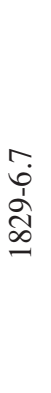 & \begin{tabular}{l}
$\frac{1}{1}$ \\
$\frac{1}{8}$ \\
\hdashline
\end{tabular} & $\cup$ & $U$ & $U$ & $U$ & $U$ & $U$ & $U$ & 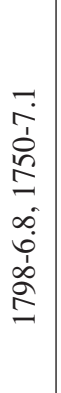 & $\begin{array}{l}\infty \\
0 \\
0 \\
1 \\
0 \\
I \\
= \\
0 \\
0 \\
0 \\
1 \\
0 \\
0 \\
I \\
I\end{array}$ & $\cup$ & $U$ & $\begin{array}{c}-1 \\
0 \\
1 \\
0 \\
-1 \\
-1 \\
0 \\
0 \\
1 \\
\overline{0} \\
0 \\
0 \\
0 \\
0 \\
1 \\
0 \\
0 \\
0\end{array}$ & $U$ & $U$ & $U$ & U \\
\hline 工 & II & II & II & II & I & I & NI & $\vec{I}$ & 可 & II & II & II & 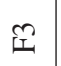 & $\overrightarrow{\text { 厌 }}$ & 届 & $\vec{I}$ & $\overrightarrow{\text { 王 }}$ & ' & ' & ' & ' \\
\hline 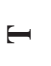 & z & Z & Z & Z & $\underset{\ominus}{U}$ & Z & Z & $\hat{\sim}$ & $\hat{\sim}$ & Z & Z & Z & $\tilde{H}$ & थे & ह & $\tilde{\Omega}$ & $\hat{n}$ & ' & ' & & \\
\hline$\alpha$ & \& & \&) & \& & $\stackrel{R}{1}$ & $\mathscr{\infty}$ & \& & 广ా & $\underset{1}{\stackrel{0}{1}}$ & $\widehat{6}$ & $\hat{\infty}_{1}$ & $\underset{\mathrm{O}}{\mathrm{O}}$ & $\stackrel{\infty}{\mathfrak{1}}$ & ๖ & $\stackrel{2}{2}$ & $\underset{\overline{6}}{\overline{1}}$ & 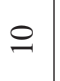 & $\stackrel{\infty}{\frac{\infty}{1}}$ & $\stackrel{\infty}{=}$ & 寺 & 肙 & $\approx$ \\
\hline$\infty$ & $\vec{m}$ & ষे & $n$ & f & ৯े & $\mathscr{\vartheta}$ & Ұ & $\hat{\sigma}$ & $\curvearrowleft$ & q & $\stackrel{\wp}{f}$ & 于 & nె & 2 & 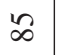 & $\infty$ & ஓ & $\widetilde{\sigma}$ & 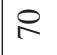 & 于 & 6 \\
\hline en & $\underset{O}{\Xi}$ & $\frac{m}{m}$ & $\frac{\sim}{m}$ & $\stackrel{n}{\curvearrowright}$ & $\stackrel{2}{n}$ & $\infty$ & $\stackrel{n}{\sim}$ & \& & $\stackrel{\infty}{\approx}$ & $\stackrel{m}{m}$ & $\hat{\vartheta}$ & $\underset{D}{Ð}$ & శి & $\bar{a}$ & $\stackrel{\infty}{\approx}$ & $\stackrel{N}{I}$ & $\curvearrowright$ & $\stackrel{\infty}{\simeq}$ & $\bar{\sigma}$ & $\hat{n}$ & 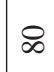 \\
\hline$\underset{\mathrm{E}}{\widehat{\Xi}}$ & $\hat{n}$ & $\begin{array}{l}\infty \\
\stackrel{0}{\infty} \\
0\end{array}$ & $\stackrel{\circ}{\circ}$ & $\stackrel{\mathfrak{N}}{\stackrel{0}{0}}$ & $\stackrel{\circ}{\circ}$ & $\stackrel{\mathfrak{V}}{\stackrel{0}{0}}$ & $\underset{\sigma}{\sigma}$ & $\underset{\text { ç }}{\text { ç }}$ & $\stackrel{\text { I. }}{\circ}$ & ñ & $\begin{array}{l}\infty \\
\infty \\
0\end{array}$ & $\underset{\ominus}{+}$ & 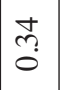 & $\stackrel{\vec{n}}{\tilde{n}}$ & $\begin{array}{l}\infty \\
n \\
0\end{array}$ & $\vec{n}$ & ণ্ণি & ' & ' & ' & ' \\
\hline 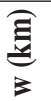 & 으 & \pm & 9 & 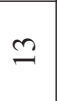 & 2 & $\underline{n}$ & $n$ & 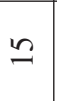 & $a$ & 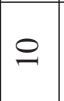 & \pm & $=$ & $\ddot{\imath}$ & ㄷ & 으 & $\infty$ & $a$ & ' & ' & ' & ' \\
\hline 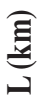 & $n$ & $\stackrel{\infty}{\sim}$ & g & $\stackrel{2}{\sim}$ & g) & $\stackrel{2}{\sim}$ & $\vec{m}$ & $\infty$ & $\overparen{\sim}$ & $n$ & $\stackrel{\infty}{\sim}$ & $I$ & $\vec{\sim}$ & $\stackrel{m}{n}$ & ஓ & I & $\stackrel{\sim}{\sim}$ & ' & ' & ' & ' \\
\hline อิ & $\begin{array}{l}\text { bे } \\
\infty \\
\text { i }\end{array}$ & 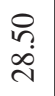 & 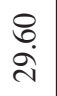 & $\begin{array}{l}\vec{\lambda} \\
\text { }\end{array}$ & $\begin{array}{l}\stackrel{n}{0} \\
\stackrel{a}{=}\end{array}$ & $\begin{array}{l}\stackrel{2}{\circ} \\
\text { ते }\end{array}$ & 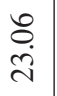 & $\underset{\check{c}}{\exists}$ & 호 & $\stackrel{\sim}{\sim}$ & $\stackrel{n}{\stackrel{n}{\sim}}$ & $\begin{array}{l}\stackrel{\infty}{n} \\
\stackrel{\sim}{N}\end{array}$ & 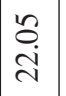 & $\begin{array}{l}8 \\
\stackrel{8}{0} \\
\end{array}$ & 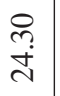 & 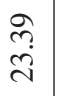 & $\frac{\sim}{n}$ & 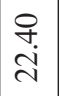 & $\begin{array}{l}\stackrel{8}{0} \\
\text { ḋ }\end{array}$ & 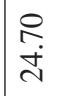 & $\begin{array}{c}8 \\
\infty \\
\infty \\
\sim\end{array}$ \\
\hline స్త్త & $\frac{\infty}{a}$ & $\begin{array}{l}\text { đa } \\
\infty \\
\infty \\
m\end{array}$ & $\frac{n}{a}$ & $\begin{array}{l}\hat{\sigma} \\
\dot{+}\end{array}$ & 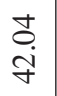 & సે & $\begin{array}{l}\hat{\sigma} \\
\infty \\
\infty \\
\infty\end{array}$ & $\begin{array}{l}\infty \\
\stackrel{\infty}{\infty} \\
\infty \\
m\end{array}$ & $\begin{array}{l}\text { ๖ } \\
\infty \\
\infty \\
m\end{array}$ & $\stackrel{\ominus}{\ominus}$ & $\begin{array}{l}\text { So. } \\
\text { ơ }\end{array}$ & $\begin{array}{l}m \\
\infty \\
m \\
m\end{array}$ & $\begin{array}{l}a \\
\overrightarrow{0} \\
m\end{array}$ & $\begin{array}{l}\stackrel{P}{0} \\
\dot{9}\end{array}$ & $\begin{array}{l}8 \\
\text { बे }\end{array}$ & $\begin{array}{l}\stackrel{0}{0} \\
\dot{\sim} \\
\dot{m}\end{array}$ & 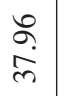 & $\left|\begin{array}{c}0 \\
\cdots \\
\infty \\
m\end{array}\right|$ & $\begin{array}{l}\stackrel{8}{a} \\
\dot{n}\end{array}$ & $\begin{array}{l}8 \\
\ddot{n} \\
\dot{m}\end{array}$ & 官. \\
\hline$\Sigma$ & $\overrightarrow{0}$ & $\ddot{\sigma}_{0}^{0}$ & 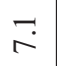 & $\tilde{\sigma}$ & $\underset{r}{r}$ & $\tilde{\sigma}$ & $\tilde{\sigma}$ & $\stackrel{N}{N}$ & ণֶ. & 7 & o & ণֶ. & $\vec{\forall}$ & $\dddot{n}$ & $\underset{0}{\forall}$ & $\stackrel{0}{0}$ & ņ & $\stackrel{\circ}{\circ}$ & $\stackrel{N}{r}$ & $\stackrel{r}{r}$ & $\stackrel{\circ}{r}$ \\
\hline ప્兀 & જે & ڤे & 尽 & $\frac{\infty}{\sigma}$ & $\frac{2}{\widehat{a}}$ & $\stackrel{\circ}{\stackrel{一}{二}}$ & $\stackrel{\infty}{\circ}$ & $\stackrel{\circ}{\circ}$ & ๙ૅ & 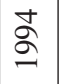 & $\stackrel{n}{2}$ & ஃ & 亏ㅇ & 天े & ్ㅗㅇ & 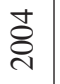 & 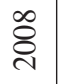 & $\stackrel{\infty}{\stackrel{\infty}{0}}$ & & $\begin{array}{l}\mathscr{2} \\
\mathscr{\infty}\end{array}$ & 兄 \\
\hline $\begin{array}{l}\text { 芯 } \\
\text { Z }\end{array}$ & 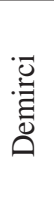 & 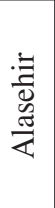 & 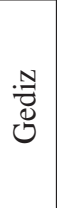 & 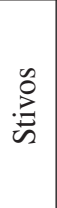 & 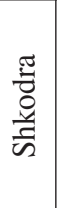 & 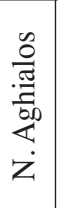 & 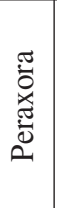 & 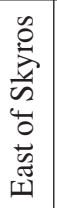 & 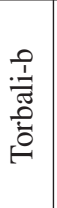 & $\stackrel{\frac{\pi}{0}}{\stackrel{0}{0}}$ & 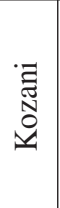 & 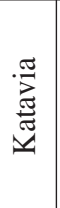 & 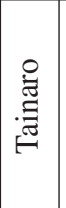 & 馬 & 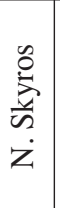 & 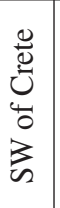 & 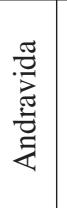 & $\begin{array}{l}0 \\
0 \\
0 \\
0 \\
0 \\
0 \\
0 \\
0 \\
\text { 崩 }\end{array}$ & 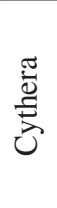 & Ũ & $\frac{0}{\frac{0}{0}}$ \\
\hline Z & $\ddot{n}$ & 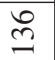 & $\hat{n}$ & $\stackrel{\infty}{m}$ & ભે & 옴 & $\exists$ & $\stackrel{Y}{ \pm}$ & $\stackrel{\mathscr{I}}{ \pm}$ & 导 & $\stackrel{\Re}{ \pm}$ & 守 & 守 & 交 & 导 & $\stackrel{n}{n}$ & $\vec{n}$ & ñ & $\tilde{n}$ & 点 & 年 \\
\hline
\end{tabular}


ate global relations for each kind of faulting. We found that the lengths of thrust and normal faults are smaller than the lengths proposed by Papazachos et al. (2001) for the same faults whereas strike-slip faults are larger. The earthquakes within each focal region were declustered in time, in order to identify the mainshocks of the region. It is found that the mainshocks exhibit quasi-periodic behaviour when the preshock and postshock time periods are both equal to 8.5 years. Regarding the completeness of the historical part of the earthquake catalogue used we found that this catalogue is complete since 1845 for mainshocks with $M \geq 6.5$ in the whole Aegean area. In many focal regions, however, completeness for earthquakes with magnitudes larger than 6.5 are extended further back in time.

\section{Acknowledgements}

Valuable and stimulating discussions with Emeritus Professor Basil. C. Papazachos are greatly acknowledged. Review by Dimitris Papanastassiou improved the manuscript.

\section{References}

Aki, K., 1966. Generation and propagation of G waves from the Niigata earthquake of June 16, 1964. Bull. Earthq. Res. Inst. Tokyo Univ., 44, 23-88.

Bonilla, M.G., Mark R.K. and Lienkaemper, J.J., 1984. Statistical relations among earthquake magnitude, surface rupture length and surface fault displacement. Bull. Seismol. Soc. Am., 74, 2379-2411.

Kanamori H. and Anderson, D.C., 1975. Theoretical basis of some empirical relations in seismology. Bull.Seism. Soc. Am., 65, 1073-1096.

Kagan, Y.Y. and Jackson, D.D., 1991. Long-term earthquake clustering. Geophys. J. Int., 104, 117-133.

Papazachos, B.C., Mountrakis, D.M., Papazachos, C.B., Tranos, M.D., Karakaisis, G.F. and Savvaidis, A.S., 2001. The faults which have caused the known major earthquakes in Greece and surrounding region between the $5^{\text {th }}$ century $\mathrm{BC}$ and today. $2^{\text {nd }}$ Greek Conference on Earthquake Engineering and Engineering Seismology, Thessaloniki, 28-30 September 2001, 1, 17-26.

Papazachos, B.C., Scordilis, E.M., Panagiotopoulos, D.G., Papazachos, C.B. and Karakaisis, G.F. 2004. Global relations between seismic fault parameters and moment magnitude of earthquakes. Bull. Geol. Soc. Greece, 36, 1482-1489.

Papazachos, B.C. and Papazachou, C.B., 2003. The earthquakes of Greece, "Ziti Publications, Thessaloniki”, 273pp.

Papazachos, B.C., Comninakis, P.E., Scordilis, E.M., Karakaisis, G.F. and Papazachos, C.B., 2009. A catalogue of earthquakes in Mediterranean and surrounding area for the period 1901-2008, Publ. Geoph. Laboratory, University of Thessaloniki.

Papazachos, C.B. and Kiratzi, A.A. 1992. A formulation for reliable estimation of active crustal deformation and an application to central Greece. Geophys. J. Int., 111, 424-432.

Reid, H.F., 1911. The elastic-rebound theory of earthquakes. Bull. Dep. Geol. Univ. Calif., 6, 412-444.

Schwartz, D.P. and Coppersmith K.J., 1984. Fault behavior and characteristic earthquake: Examples from the Wasatch and San Andreas fault zones. J. Geophys. Res., 89, 5681-5698.

Smith G.C. and Stock Ch., 2000. Evidence for different scaling of earthquake source parameters for large earthquakes depending on faulting mechanism. Geophys. J. Int., 143, 157-169.

Wells D.L. and Coppersmith K.J., 1994. New empirical relationships among magnitude, rupture length, rupture width, rupture area and surface displacement. Bull. Seism. Soc. Am., 84, 974-1002.

Wesnousky S.G., 1986. Earthquake, quaternary faults and seismic hazard in California. J. Geophys. Res., 91, 12587-12631. 